\title{
PROCESSING IN THE QUALITY OF TANZANIA GRASS SEEDS
}

Doi:http://dx.doi.org/10.1590/1809-4430-Eng.Agric.v36n6p1157-1166/2016

\section{LILIAN F. DE MELO ${ }^{1 *}$, CIBELE C. MARTINS ${ }^{2}$, GIVANILDO Z. DA SILVA², MAURICIO F. G. SANCHES ${ }^{2}$}

1*Corresponding author. UNESP/ Jaboticabal - SP, Brazil. E-mail: lilianfariamelo@gmail.com

\begin{abstract}
The available research concerning the processing of grass seeds is scarce, despite its fundamental importance for national and international agribusiness. The objective of this project was to evaluate the effects of processing phases on the physical and physiological quality of tanzania grass seeds for commercialization purposes. Seeds were sampled before processing and after leaving the air and screen machine (upper and intermediate screens and bottom); first gravity table (drift, upper and intermediate spouts); treating machine; second gravity table (upper, intermediate, and lower spouts). Seeds were evaluated as to water content, physical quality (purity and 1,000 seeds weight) and physiological (germination, first count of germination, seedling vigor rating, seedlings length of primary roots and shoots, seedling emergence in the field, and emergence speed index). The processing of Tanzania grass seeds in the air screen cleaner machine and gravity table are efficient to improve the physical quality of the lot. The seed treatment with dye ink reduces the seedlings emergence speed in the field. The processing is not required to meet the national commercialization standards of the Tanzania grass seeds, but for the international.
\end{abstract}

KEYWORDS: germination, Panicum maximum, pastures, tropical grass, vigor.

\section{INTRODUCTION}

Brazil stands out as the largest producer, exporter and consumer of forage grass seeds (CARDOSO et al., 2014). At harvest, this seeds are gathered by sweeping the soil after dispersion and present large amounts of impurities that must be removed by processing, such as empty spikelets, earth, sand, straw, stones, weed seeds and other impurities (NERY et al., 2009; HESSEL et al., 2012).

Furthermore, because they are not domesticated plants, the forage grass have uneven maturation of spikelets in the bunch and, at harvest, the lot is heterogeneous, consisting of seeds of different sizes, density, germination and vigor (MASCHIETTO et al., 2003; MENDONÇA et al., 2015). Therefore, several characteristics need to be improved in the processing method to address the needs of the domestic and international markets aimed at commercialization and sowing (MASCHIETTO et al., 2003; HESSEL et al., 2012; QUADROS et al., 2012).

The processing of seeds can be defined as the set of sequential operations after they were received in the Seed Processing Unit (SPU), designed to enhance the characteristics of the lot through homogenization and improvement mainly of physical, but also of physiological quality (FERREIRA \& SÁ, 2010; PEREIRA et al., 2012; HESSEL et al., 2012).

The physical component refers to the physical purity of the lot and the seed physical condition, which covers the water content, size, density and uniformity of these characteristics. The physiological component refers to the longevity potential and its ability to generate a perfect and vigorous plant being influenced by the environment in which the seeds were formed and by harvesting, drying, processing and storage conditions (CARVALHO \& NAKAGAWA, 2012).

The processing of grass seeds such as rice in the air screen cleaner machine and gravity table (PEREIRA et al., 2012) and Brachiaria brizantha cv. Marandu only in gravity table (HESSEL et al., 2012) allowed the improvement of physical and physiological quality of the lot. However, depending on the species and size of seeds, only the physiological quality is improved by passing

\footnotetext{
${ }^{2}$ Universidade Estadual Paulista - UNESP/ Jaboticabal - SP, Brasil. 
through the machines, as was observed for corn, whose lot already shows high physical purity when is received in the SPU (FERREIRA \& SÁ, 2010).

The seed processing machines perform operations based on physical differences (specific weight, density, size and shape) between seeds and impurities, so that the removal of unwanted components and the choice of the machines depend on the type of seed, the specie, the nature and the amount of impurities and the desired characteristics of the received material. Therefore, not all lots follow the same sequence during the processing (FERREIRA \& SÁ, 2010; LOPES et al., 2011).

For forage seed processing is usually used the air screen machines that perform the separations based on physical differences between the materials in the lot, such as size and specific weight; and the gravity table that separates by specific weight (NERY et al., 2009; HESSEL et al., 2012). Another machine would be the seed treater, used optionally, given that some foragers companies adopt the coating of these with dyes, polymers and other products to provide a more attractive appearance to the consumer market (PEREIRA et al., 2011; OLIVEIRA et al., 2014a; MELO et al., 2016).

The aim of this study was to evaluate the effect of the processing steps in the physical and physiological quality of $P$. maximum $\mathrm{cv}$. Tanzania seeds aiming the commercialization.

\section{MATERIAL AND METHODS}

The seeds of Panicum maximum cv. Tanzania were harvested mechanically by ground sweeping (Racing 3500 Hercules model harvester) in the 2012/2013 harvest in Jales - SP and $14,120 \mathrm{~kg}$ of gross seeds were sent to the Seed Processing Unit (SPU) of forage grasses in Ribeirão Preto-SP. The processing yield was $69 \%$ because at the end of process it was obtained $9,758 \mathrm{~kg}$ of commercial seeds.

The processing was carried out by passing the seeds by an air screen cleaner machine, two gravity tables and a seed treater. After the stabilization of the operating equipment, about six hours after the beginning of the process, the seeds of each processing stage and the disposal from the machines were sampled at regular intervals of five minutes between repetitions, resulting in approximately 20 single samples per treatment, with an average weight of $100 \mathrm{~g}$, obtained at different disposal spouts machines, according to the flow chart as shown in Figure 1.

For each treatment, the samples were clustered and homogenized in compound samples of approximately $2,000 \mathrm{~g}$ and reduced to form average samples of $500 \mathrm{~g}$ which were submitted to laboratory analysis (BRASIL, 2009).

Thus it was obtained 11 treatments at different stages of processing, as described below: control consisting of gross seed, unprocessed (T1). 


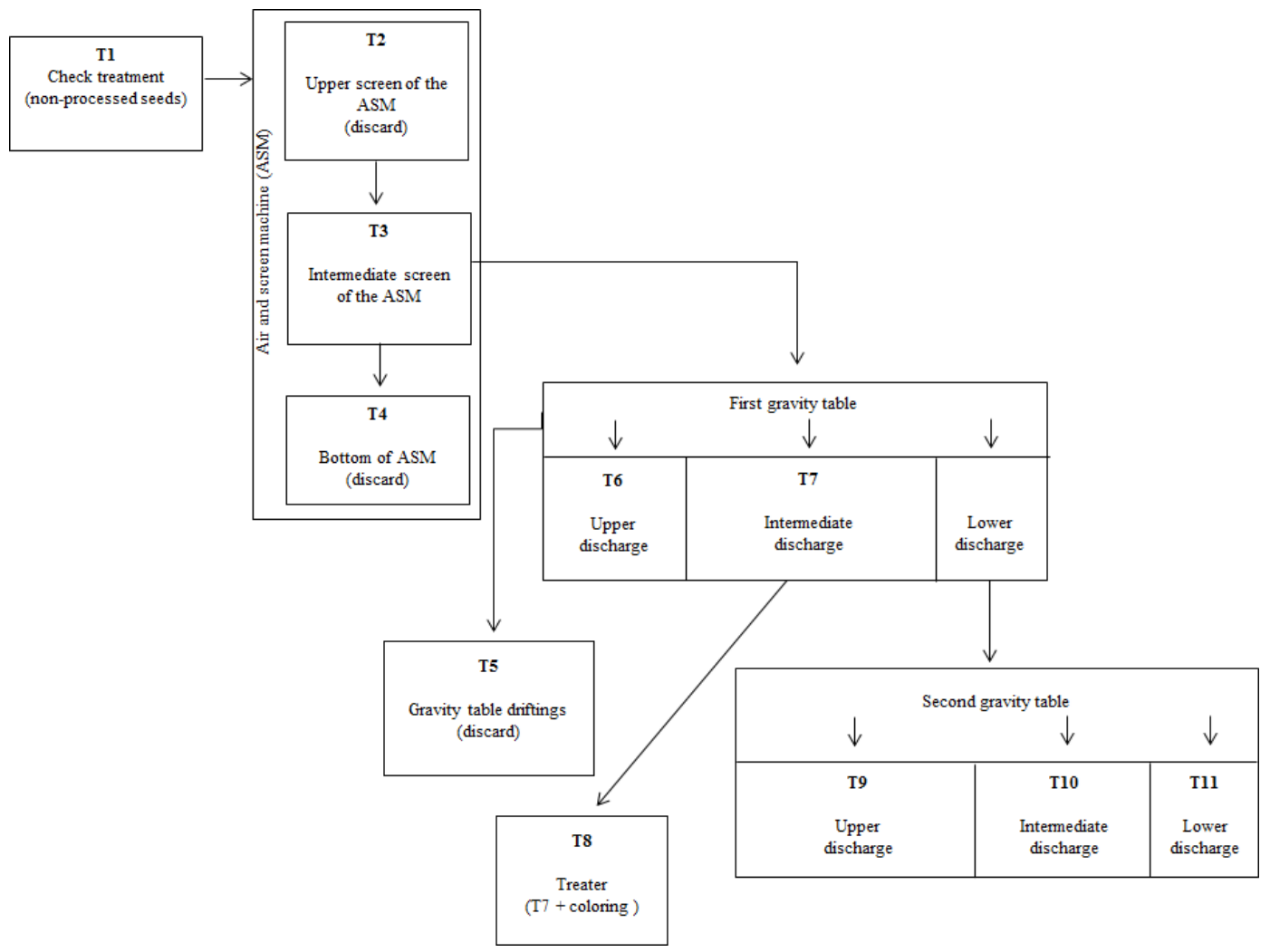

FIGURE 1. Processing phases and the points where seed samples were taken (T1, T2, T3, T4, T5, T6, T7, T8, T9, T10 e T11).

Air and screen machine (ASM) - after passing through the air screen cleaner the samples were collected from the retained material on the upper sieve, of round sieves with a diameter of $7 / 32$ inch $(5.56 \mathrm{~mm}),(\mathrm{T} 2)$; intermediate sieve of braided mesh 20 yarn AWG (diameter of $0.8118 \mathrm{~mm}$ ) square holes with 30x30 mm openings (T3); metal plate bottom that retains small material which passed through the sieves (T4). The seed company routinely considers disposals T2 and T4.

First gravity table (GTI) - was sampled the drift material removed by vacuum at the entrance of this machine, considered disposal by the company (T5). This equipment had $2.40 \mathrm{~m}$ surface long, $1.25 \mathrm{~m}$ wide, vibration speed of $1,750 \mathrm{rpm}, 17^{\circ}$ and $12^{\circ}$ of transverse and longitudinal tilting, respectively. After passing the first gravitational table samples were collected from the upper disposal consisting of material fraction collected at $35 \mathrm{~cm}$ from the highest end of the table output when considering its lateral tilt (T6) and in the intermediate disposal, composed by the material collected on the intermediate segment of $60 \mathrm{~cm}$ from the table output (T7). The seeds from the lower disposal consisting of material fraction collected on the segment of $30 \mathrm{~cm}$ from the lower end of the table when considering its lateral tilting, were not sampled, but transferred into a second gravity table.

Seed treater - following; only the seeds from the intermediate disposal of the first gravity table were subjected to dyeing, just to improve seeds appearance, achieved by spraying the green dye of Laborsan Brasil ${ }^{\circledR}$ and mechanical movement of the mass in the treater machine Seed Mix VHM4/10 T (T8).

Second gravity table (GTII) - seeds were sampled after passing the second gravity table, identical to the first, but with the settings of the different disposals, since the upper was composed of material fraction collected on the $60 \mathrm{~cm}$ segment from the higher end of the table output (T9); the intermediate disposal, composed by the material collected in the intermediate segment of $45 \mathrm{~cm}$ (T10) and bottom disposal, composed by the material collected on the $20 \mathrm{~cm}$ segment of the lower edge (T11). 
The divisions of the disposals in both gravitational tables were adjusted in order to allow greater concentration of undesirable materials at the lower disposal and therefore are of different sizes, as illustrated in Figure 2.
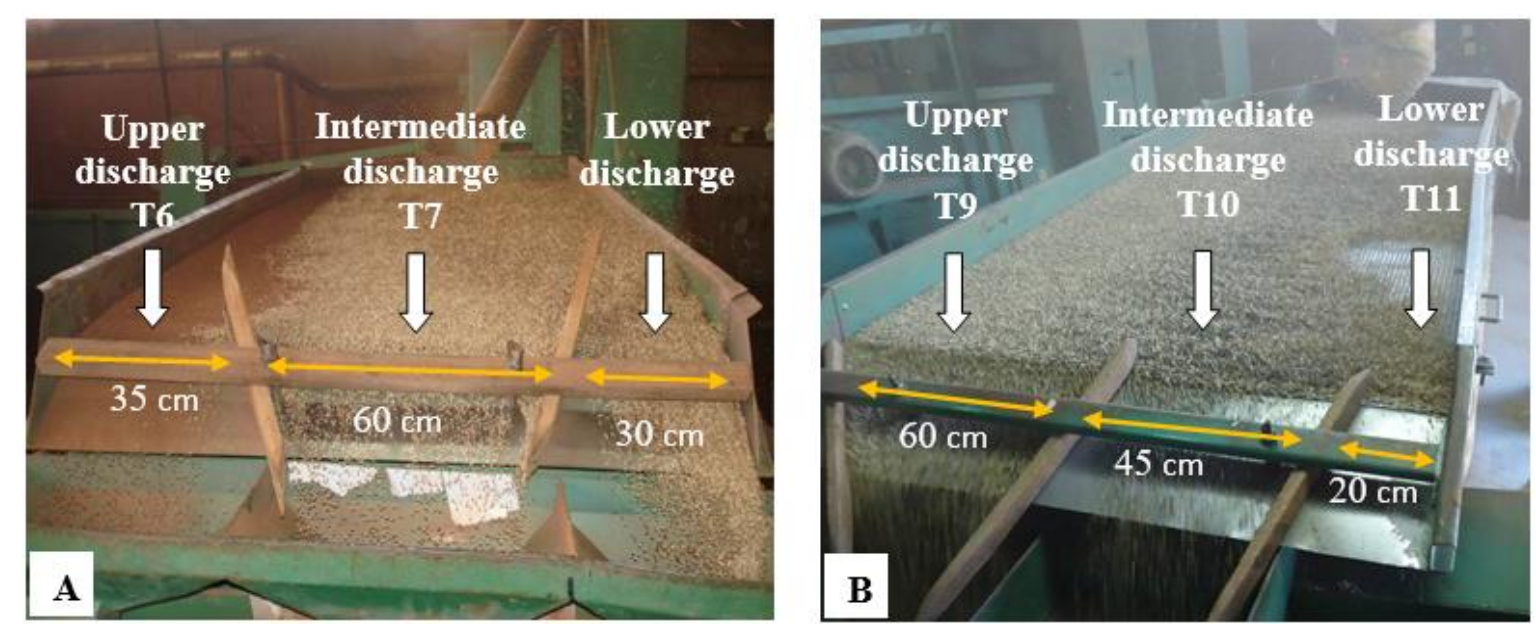

FIGURE 2. Points where samples were taken from the first (A) and second gravity table (B). The lower extremity was considered that located at the lowest point of the spout when the lateral inclination of the table was considered and, as the upper, the opposite extremity.

The average samples were received at the Seed Analysis Laboratory, of the Department of Plant Production - Plant Science, from the Agricultural and Veterinary Sciences College (UNESP), Jaboticabal - SP and reduced in soil divider for obtaining the research sample (BRASIL, 2009). For the evaluation of seed quality the following testing and determinations were performed:

Water content - determined using the oven method at $105 \pm 3^{\circ} \mathrm{C}$ for 24 hours, using two subsamples of $2 \mathrm{~g}$ of seeds per treatment, in precision scales $(0.001 \mathrm{~g})$ and data expressed as percentage with one decimal (BRASIL, 2009).

Physical purity - determined using two subsamples of $8 \mathrm{~g}$, which were weighed on a precision scale $(0.001 \mathrm{~g})$, the cleaning performed in sieves and passing in pneumatic blower complemented by manual separation to obtain pure seed, with the results expressed in percentage (BRASIL, 2009). The weight of the subsamples higher than the recommended by the Rules for Seed Analysis (RSA) was used to ensure greater representation of the components present in the lot and to achieve the appropriate number of seeds to carry out all the proposed tests and determinations.

Thousand seed weight - determined using eight subsamples of 100 seeds taken from the portion of pure seeds weighted individually in precision scale $(0.001 \mathrm{~g})$, with the results expressed in gram (BRASIL, 2009).

Germination tests - conducted with four subsamples of 50 seeds sown on two sheets of filter type wetted with $\mathrm{KNO}_{3}(0.2 \%)$ in the amount of twice the paper mass, in transparent plastic boxes $(11.0 \times 11.0 \times 3.5 \mathrm{~cm})$, and individually wrapped in plastic bags $0.05 \mathrm{~mm}$ thick for the maintenance of substrate moisture at alternating temperature of $15-35^{\circ} \mathrm{C}$ with photoperiod of $8 \mathrm{~h}\left(78 \mu \mathrm{mol} \mathrm{s}{ }^{-1}\right.$ $\left.\mathrm{m}^{-2} / 8 \mathrm{~h}\right)$. It was considered germinated the normal seedlings present at the $28^{\text {th }}$ day after sowing (BRASIL, 2009; TOMAZ et al., 2010).

For the detection of dormancy, the remaining seeds of the germination test were submitted to the tetrazolium test. The seeds were cut longitudinally and medially through the embryo and one of the seed halves was immersed in a tetrazolium solution of $0.1 \%$, maintained in a dark chamber at $37^{\circ} \mathrm{C}$ for three hours. After this period the seeds were washed in distilled water and the reading was done immediately, classifying the seeds in viable (dormant) and non-viable (dead) (TOMAZ et al., 2010).

First germination count - performed together with the germination test, computing the percentage of normal seedlings obtained on the seventh day after sowing (BRASIL, 2009). 
Seedling vigor rating - conducted jointly with the germination test, evaluating in the date of the first counting of this test the well-developed normal seedlings, which were removed and counted. Later on in the period corresponding to final count, the remaining seedlings were evaluated and the most vigorous normal seedlings and classified as "strong" were added to those of the first count (OLIVEIRA et al., 2014b). The results were expressed in terms of mean percentage of strong normal seedlings (vigorous).

Seedling emergence in the field - evaluated by sowing four subsamples of 100 pure seeds per treatment in the spacing of $0.2 \mathrm{~m}$ between rows at a depth of two centimeters, the counts were conducted daily until 28 days after sowing and results expressed in percentage (OLIVEIRA et al., 2014b).

Seedlings length of primary roots and shoots - carried out with four subsamples of 20 seeds sown on a line drawn in the upper third of the substrate paper towel, pre-moistened with distilled water, in the amount of twice the mass of the paper, kept at $25^{\circ} \mathrm{C}$ for 14 days. After 14 days remaining in germination chamber, the normal seedlings obtained were separated by measuring the length of primary root and shoot, with the aid of a ruler with millimeter graduation. The average length of the seedling primary root and shoot was obtained by the measurements average of each normal seedling in each repetition. The results were expressed in centimeters per plant (OLIVEIRA et al., 2014b).

Seedling emergence speed index - was conducted in conjunction with the emergency field testing, counting on a daily basis, at the same time, the number of emerged seedlings up to 28 days after sowing. The index calculation was carried out by applying to the collected data the formula proposed by MAGUIRE (1962).

The experimental design used was completely randomized, with four replications and 11 treatments (stages of the processing method). The data were not transformed because they met the assumptions of the normality and homogeneity tests; were subjected to analysis of variance and when significant, the means were compared by Tukey test at $5 \%$ probability.

\section{RESULTS AND DISCUSSION}

The water contents of the seeds from the different processing stages were between 7.1 and $8.9 \%$. This similarity values is essential so that the tests are not affected by differences in metabolic activity and seed wetting speed. It is recommended that there are no differences greater than $2 \%$ of water content in the seed samples (STEINER et al., 2011).

At different processing stages, the physical purity varies from 2.8 to $95.5 \%$ (Table 1). 
TABLE 1. Physical purity (P), 1.000 seeds weight (TSW), germination (G), first germination count (FG), seedling vigor rating (SVR), seedling emergence in the field (SEF), length of shoots (LS), and seedling emergence speed index (ESI) of Panicum maximum cv. Tanzania seeds after processing phases.

\begin{tabular}{|c|c|c|c|c|c|c|c|c|}
\hline Treat & $\begin{array}{c}\mathrm{P} \\
(\%)\end{array}$ & $\begin{array}{c}\text { TSW } \\
(\mathrm{g})\end{array}$ & G & FG & $\begin{array}{c}\text { SVR } \\
\%)-\end{array}$ & SEF & $\begin{array}{l}\mathrm{LS} \\
(\mathrm{cm})\end{array}$ & ESI \\
\hline 1 Check treotm & $71.5 \mathrm{c}$ & $1.15 \mathrm{c}$ & $74 \mathrm{a}$ & $72 \mathrm{a}$ & $70 \mathrm{a}$ & $49 \mathrm{a}$ & $4.2 \mathrm{a}$ & $6.7 \mathrm{a}$ \\
\hline $\mathrm{T} 2-\mathrm{I}$ & $8.7 \mathrm{e}$ & $1.04 \mathrm{~d}$ & $75 \mathrm{a}$ & $73 \mathrm{a}$ & $52 \mathrm{~b}$ & $48 \mathrm{a}$ & $4.2 \mathrm{a}$ & $6.2 \mathrm{ab}$ \\
\hline of the ASM & $80.0 \mathrm{~b}$ & $1.13 \mathrm{c}$ & 79 a & $77 \mathrm{a}$ & $72 \mathrm{a}$ & $50 \mathrm{a}$ & $4.1 \mathrm{a}$ & $6.6 \mathrm{a}$ \\
\hline $\mathrm{ASM}^{1}$ & $2.8 \mathrm{e}$ & $0.67 \mathrm{e}$ & $27 \mathrm{~b}$ & $26 \mathrm{~b}$ & $23 \mathrm{c}$ & $26 \mathrm{~b}$ & $3.8 \mathrm{ab}$ & 3.3 \\
\hline $\mathrm{T} 5-\mathrm{c}$ & $2.4 \mathrm{e}$ & $0.57 \mathrm{f}$ & $5 \mathrm{c}$ & $5 \mathrm{c}$ & $3 d$ & $6 c$ & $2.4 \mathrm{bc}$ & $0.7 \mathrm{~d}$ \\
\hline $6-1$ & $55.5 \mathrm{~d}$ & $1.27 \mathrm{a}$ & 79 a & $78 \mathrm{a}$ & $72 \mathrm{a}$ & $50 \mathrm{a}$ & $3.7 \mathrm{ab}$ & $7.0 \mathrm{a}$ \\
\hline 57 - & $95.5 \mathrm{a}$ & $1.26 \mathrm{a}$ & $81 \mathrm{a}$ & $80 \mathrm{a}$ & $73 \mathrm{a}$ & $48 \mathrm{a}$ & $4.2 \mathrm{a}$ & $5.8 \mathrm{a}$ \\
\hline & $93.8 \mathrm{a}$ & $1.23 \mathrm{ab}$ & $76 \mathrm{a}$ & $73 \mathrm{a}$ & $72 \mathrm{a}$ & $41 \mathrm{a}$ & $3.6 \mathrm{abc}$ & $5.5 \mathrm{~b}$ \\
\hline T9 - L & $92.0 \mathrm{a}$ & $1.19 \mathrm{bc}$ & 79 a & $78 \mathrm{a}$ & $68 \mathrm{a}$ & $46 a$ & $3.6 \mathrm{abc}$ & $5.9 \mathrm{ab}$ \\
\hline T10 - & $4.2 \mathrm{e}$ & $0.36 \mathrm{~g}$ & $10 \mathrm{c}$ & $10 \mathrm{c}$ & $4 d$ & $8 \mathrm{c}$ & $2.0 \mathrm{c}$ & $1.1 \mathrm{~d}$ \\
\hline T11 - Lov & $5.0 \mathrm{e}$ & $0.73 \mathrm{e}$ & $9 \mathrm{c}$ & $8 \mathrm{c}$ & $7 \mathrm{~d}$ & $8 \mathrm{c}$ & $3.3 \mathrm{abc}$ & $1.1 \mathrm{~d}$ \\
\hline C. V. \% & 3.6 & 4.1 & 6.5 & 6.9 & 6.5 & 11.7 & 18.7 & 10.9 \\
\hline
\end{tabular}

** Significant at $1 \%$ probability by F. Average test followed by the same letter in the column do not differ by Tukey test at $5 \%$ probability.

ASM- Air and screen machine, GT I- First gravity table, GT II- Second gravity table, CV- coefficient of variation.

1. Processing Steps that result in material disposal by the company, because they have more than $90 \%$ of impurities in its composition.

According to Normative Instruction (NI) $n^{\circ} 30$, from the Ministry of Agriculture, Livestock and Supply - MAPA (BRASIL, 2008), the minimum purity standard for the commercialization of certified seed of $P$. maximum gender is $50 \%$. Thus, based only on the purity characteristics, the original unprocessed lot (T1) would be able to be commercialized as seed in the domestic market, because it showed $71.5 \%$ purity. Just like the seeds from the upper disposal from the first gravity table (T6), which had even less purity of 55\%, due to the high incidence of soil clods and stones (BRASIL, 2008). The presence of these impurities at the samples collection point of this treatment can be seen in Figure 2A.

However, the processing enables the increase of physical purity, as observed in seeds from the intermediate sieve of the air screen cleaner machine (T3), intermediate disposal of the first gravity table (T7) after passing through the treater (8) and upper discharge of the second gravity table (T9) (Table 1).

These results indicated the importance of using air screen cleaner machine and gravity table on $P$. maximum seed processing because the use of these machines enabled the improvement of physical purity and visual appearance of the seed lot (CARVALHO \& NAKAGAWA, 2012). HESSEL et al. (2012) highlighted the importance of raising these physical attributes of forage grass seeds, because due to the intrinsic characteristics of the species and harvesting methods employed for production, these often have low quality.

Aiming at the foreign market, the processing would be essential because most Latin American countries are using Brazilian seeds to form their pastures, and only purchase products with purity levels between 90 and 95\% (MASCHIETTO \& BATISTA, 2005). Thus, only the seeds from the intermediate disposal of the first gravity table (T7) after passing the treater (T8) and upper disposal of the second gravity table (T9) would be able to meet the requirements of the international market.

Samples from the upper and bottom sieve at the air screen cleaner machine (T2 and T4), derived from the first gravity table (T5), intermediate and lower disposal of the second gravity table (T10 and T11) had a purity of between 2.4 and $8.7 \%$, which means that more than $90 \%$ of this material was composed of impurities and thus would be discarded by the company (BRASIL, 2008; BRASIL, 2009). In general, impurities observed from the treatments were straw, stones, soil clods 
and other seeds, mainly Brachiaria brizantha L. All samples obtained from the middle and lower disposal of the second gravity table (T10 and T11) predominated empty spikelets and straw because they are lighter materials (Figure 2).

Similarly, in studies of Brachiaria brizantha seeds processing (HESSEL et al., 2012), rice (PEREIRA et al., 2012), soybean (SILVA et al., 2011), maize (FERREIRA \& SÁ, 2010) and forage radish (NERY et al., 2009), also predominated as impurities straws, stones, soil clods, weed seeds and immature seeds; but also damaged and attacked seeds by fungi and insects.

Regarding the thousand seed weight, it was observed that the heavier seeds are from the upper and intermediate disposal of the first gravity table and treater (T6, T7 and T8), compared to the control (T1) and the disposal of the second gravity table (T9) did not differ from these treatments and neither by the control. The similar seeds weight from the intermediate disposal of the first gravity table (T7) and treater (T8) is expected, as the latter only dyed the seeds of the previous treatment.

These results demonstrate the processing efficiency of improving the physical quality of the seeds when used as separation based on density. Similar results were found by MELO et al. (2016) with guinea grass seeds, GADOTTI et al. (2012) with tobacco seeds, HESSEL et al. (2012) with Brachiaria brizantha seeds and PEREIRA et al. (2012) with rice seeds.

As for germination, it was found that the seeds coming from the upper and intermediate sieves of the air screen cleaner machine (T2 and T3), higher and intermediate disposal of the first gravity table (T6 and T7), seed treater (T8) and upper disposal of the second gravity table (T9), do not differ from the unprocessed control. These treatments as well as the control (T1) showed higher germination to the minimum established for $P$. maximum that according to NI $\mathrm{n}^{\circ} 30$ (BRASIL, 2008), which is $40 \%$ for certified seeds.

Thus, based on germination and purity characteristics, the original unprocessed lot (T1) would be able to be commercialized as seed in the domestic market, eliminating the need to spend time, energy and manpower with the processing operations (BRASIL, 2008). It should be emphasized that the current sales price of forage grass seeds for the international market is 1.6 times higher than the national: approximately US\$ $2.37 / \mathrm{kg}$ and US\$ $3.83 / \mathrm{kg}$ for the domestic and international markets, respectively (PEREIRA, 2015*).

Similar results, of germination superiority after the classification of seeds in the air screen cleaner machine and gravity table were also observed for Brachiaria brizantha seeds (HESSEL et al., 2012), rice (PEREIRA et al., 2012) and tobacco ( GADOTTI et al., 2011).

The seeds used in the study showed no dormancy because by the tetrazolium test (data not shown) the remaining seeds were dead. Dormancy occurs most frequently by freshly harvested seeds and harvested in the bunch, being naturally overcome by the harvest on the ground (MASCHIETTO et al., 2003).

The results of vigor tests of the first germination count, classification of seedling vigor, shoot length, seedling emergence in the field and emergency speed index are shown in Table 1, but it will be only discussed the samples vigor that can be considered seeds for presenting purity and germination within allowable standards for the production and commercialization of forage seed species (BRASIL, 2008), that is, from the seed of five treatments: control (T1), intermediate sieve of the air screen cleaner machine (T3), superior and intermediate disposal of the first gravity table (T6 and T7), treater (T8) and upper disposal of the second gravity table (T9).

The seedlings root length was not a characteristic influenced by the processing and, therefore, the data were not presented in the table.

\footnotetext{
* MATHEUS PEREIRA, Marangatú Seeds, personal communication, 07/2015.
} 
The seeds of the control treatment (T1), intermediate sieve of the air screen cleaner machine (T3), superior and intermediate disposal of the first gravity table (T6 and T7), treater (T8) and upper disposal of the second gravity table (T9) presented maximum vigor according to almost all tests (first germination count, seedling vigor classification, seedlings shoot length, and seedling emergence in the field).

The emergence speed, measured by the ESI, was affected by the seed treatment with dye ink, being the only one among the treatments considered seeds, which significantly reduced this parameter compared to the control. These results allowed us to observe a possible phytotoxic effect of the dye on the seedling during the emergency in the field.

Even though some products may seem innocuous, their use in seeds treatment may harm the physiological potential of them as observed in the coating of Brachiaria decumbens seeds with sand and microcellulose (PEREIRA et al., 2011; SANTOS et al. 2010). In addition, application of dye implies in wetting and subsequent drying of the seeds, which must be done quickly to prevent imbibition and loss of vigor (CARVALHO \& NAKAGAWA, 2012; SILVA \& ROSSETTO, 2012).

\section{CONCLUSIONS}

The processing of Tanzania grass seeds in the air screen cleaner machine and gravity table are efficient to improve the physical quality of the lot.

The seed treatment with dye ink reduces the seedlings emergence speed in the field.

The processing is not required to meet the national commercialization standards of the Tanzania grass seeds, but for the international.

\section{REFERENCES}

BRASIL. Ministério da Agricultura, Pecuária e Abastecimento. Regras para análise de sementes. Brasília: MAPA/ACS, 2009. 399p.

BRASIL. Ministério da Agricultura, Pecuária e do Abastecimento Gabinete do Ministro. Instrução Normativa ${ }^{\circ}$ 30, de 21 de maio de 2008. Publicado no Diário Oficial da União, Poder Executivo, Brasília, DF, 23 de maio de 2008, Seção 1, p.45. Disponível em:

<http://sistemasweb.agricultura.gov.br/sislegis/action/detalhaAto.do?method=consultarLegislacaoFederal>. Acesso em: 18 ago. 2015.

CARDOSO, E. D.; SÁ, M. E.; HAGA, K. I.; BINOTTI, F. F. S.; NOGUEIRA, D. C.; VALERIO FILHO, W. V. Desempenho fisiológico e superação de dormência em sementes de Brachiaria brizantha submetidas a tratamento químico e envelhecimento artificial. Semina: Ciências Agrárias, Londrina, v. 35, n. 1, p. 21-38, jan/fev. 2014.

CARVALHO, N. M.; NAKAGAWA, J. Sementes: ciência, tecnologia e produção. Jaboticabal: FUNEP, 2012. 590p.

FERREIRA, R. L.; DE SÁ, M. E. Contribuição de etapas do beneficiamento na qualidade fisiológica de sementes de dois híbridos de milho. Revista Brasileira de Sementes, Londrina, v. 32, n. 4, p. 99-110, 2010.

GADOTTI, G. I.; BAUDET, L.; VILELLA, F. A. Several regulations in gravity table in quality of tobacco seeds. Engenharia agrícola, Jaboticabal, v. 32, n. 2, p. 361-368, mar./abr. 2012.

GADOTTI, G. I.; VILELLA, F. A.; BAUDET, L. Influência da mesa densimétrica na qualidade de sementes de cultivares de tabaco. Revista Brasileira de Sementes, Londrina, v. 33, n. 2, p. 372378, 2011.

HESSEL, C. L. E.; VILLELA, F. A.; AUMONDE, T. Z.; PEDÓ, T. Mesa densimétrica e qualidade fisiológica de sementes de brachiaria. Informativo ABRATES, Londrina, v. 22, n. 3, p. 73-76, 2012. 
LOPES, M. M.; PRADO, M. O. D.; SADER. R.; BARBOSA, R. M. Efeitos dos danos mecânicos e fisiológicos na colheita e beneficiamento de sementes de soja. Bioscience Journal, Uberlândia, v. 27, n. 2, p. 230-238, mar/abr. 2011.

MAGUIRE, J. D. Speed of germination-aid selection and evaluation for seedling emergence and vigor. Crop Science, Madison, v. 2, n. 2, p. 176-177, 1962.

MASCHIETTO, J. C.; BATISTA, R. W. M. Semente de pastagem com alto valor cultural. Revista JC Maschietto, Penápolis, v.3, n.3, 2005. Disponível em: <

http://www.jcmaschietto.com.br/index.php?link=artigos\&sublink=artigo_16 >. Acesso em: maio 2015.

MASCHIETTO, R. W.; NOVEMBRE, A. D. L. C.; SILVA, W. R. Métodos de colheita e qualidade das sementes de capim colonião cultivar Mombaça. Bragantia, Campinas, v. 62, n. 2, p. 291-296, 2003.

MELO, L. F.; MARTINS, C. C.; SILVA, G. Z.; BONETI, J. E. B.; VIEIRA, R. D. Beneficiamento na qualidade física e fisiológica de sementes de capim-mombaça. Revista Ciência Agronômica, Fortaleza, v. 47, n. 4, p. 667-674, out/dez. 2016.

MENDONÇA, G. S.; MARTINS, C. C.; MARTINS, D.; LOPES, M. T. G. Aspectos físicos e fisiológicos de sementes de Fimbristylis dicothoma relacionados à germinação e dormência.

Revista Ciência Agronômica, Fortaleza, v. 46, n. 3, p. 539-545, jul/set. 2015.

NERY, M. C.; CARVALHO, M. L. M.; OLIVEIRA, J. A.; KATAOKA, V. Y. Beneficiamento de sementes de nabo forrageiro. Revista Brasileira de Sementes, Londrina, v.31, n.4, p. 36-42, 2009.

OLIVEIRA, E. P.; SILVEIRA, L. P. O.; TEODORO, P. E.; ASCOLI, F. G.; TORRES, F. E. Efeito do sombreamento e do incrustamento de sementes sobre o desenvolvimento de cultivares de Panicum maximum Jacq. Bioscience Journal, Uberlândia, v.30, n.6, p. 1682-1691, nov/dez. 2014a.

OLIVEIRA, S. S. C.; MARTINS, C. C.; CRUZ, J. S.; SILVA, J. C. Seleção de progênies de naboforrageiro para germinação sob altas temperaturas. Ciência Rural, Santa Maria, v. 44, p. 217-222, fev. 2014b.

PEREIRA, C. E.; ALBURQUERQUE, K. S.; OLIVEIRA, J. A. Qualidade física e fisiológica de sementes de arroz ao longo da linha de beneficiamento. Semina: Ciências Agrárias, Londrina, v. 33, n. 1, p. 2995-3002, 2012.

PEREIRA, C. E.; OLIVEIRA, J. A.; ROSA, M. C. M.; KIKUTI, A. L. P. Armazenamento de sementes de braquiária peletizadas e tratadas com fungicida e inseticida. Ciência. Rural, Santa Maria, v.41, n.12, p. 2060-2065, dez. 2011.

QUADROS, D. G.; ANDRADE, A. P.; OLIVEIRA, G. C.; OLIVEIRA, E. P.; MOSCON, E. S. Componentes da produção e qualidade de sementes dos cultivares marandu e xaraés de Brachiaria brizantha (Hochst. ex A. Rich.) Stapf colhidas por varredura manual ou mecanizada. Semina: Ciências Agrárias, Londrina, v. 33, n. 5, p. 2019-2028, set/out. 2012.

SANTOS, F. C.; OLIVEIRA, J. A.; VON PINHO, E. V. R.; GUIMARAES, R. M.; VIEIRA, A. R. Tratamento químico, revestimento e armazenamento de sementes de Brachiaria brizantha cv. Marandu. Revista Brasileira de Sementes, Londrina, v.32, n.3, p. 69-78, set. 2010.

SILVA, L. F.; ROSSETTO, C. A. V. Potencial fisiológico de sementes de girassol influenciado pelo umedecimento artificial. Ciencia Rural, Santa Maria, v.42, n.7, p.1161-1167, 2012.

SILVA, R. P.; TEIXEIRA, I. R.; DEVILLA, I. A.; REZENDE, R. C.; SILVA, G. C. Qualidade fisiológica de sementes de soja (Glycine max. L.) durante o beneficiamento. Semina: Ciências Agrárias, Londrina, v. 32, n. 4, p. 1219-1230, out/dez. 2011. 
STEINER, F., OLIVEIRA, S. S. C., MARTINS, C. C., CRUZ, S. J. S. Comparação entre métodos para a avaliação do vigor de lotes de sementes de triticale. Ciência Rural, Santa Maria, v. 41, n. 2, p. 200-204, fev. 2011.

TOMAZ, C. A.; MARTINS, C. C.; CARVALHO, L. R.; NAKAGAWA, J. Duração do teste de germinação do capim-tanzânia. Revista Brasileira de Sementes, Londrina, v. 32, n. 4, p. 80-87, 2010. 